УДК 330.131 .52

(C) 2012

Бабицький Л. Ф., доктор технічних наук

Південний філіал НУБіП

Падалка В. В., кандидат технічних наук

Полтавська державна аграрна академія

Ляшенко С. В., інженер

Полтавська державна аграрна академія

\title{
ЕКОНОМІЧНА ЕФЕКТИВНІСТЬ ВИРОБНИЧОГО ВПРОВАДЖЕННЯ ТОРСІОННО-УДАРНОГО РОЗПУШУВАЧА ІРУНТУ
}

\section{Рецензент - доктор технічних наук, професор В. П. Дмитриков}

\begin{abstract}
Обтрунтована необхідність застосування активних розпушувачів для покращання фізикомеханічних властивостей трунту сільськогосподарських угідь. Наведено результати розрахунків економічної ефективності використання торсіонно-ударного розпушувача трунту. Підтверджено економічну ефективність його виробничого впровадження. Експериментально доведено економію палива при виконанні технологічного процесу безвідвального обробітку трунту машиннотракторним агрегатом у складі МТЗ-80 + торсіонно-ударний розпушувач трунту в порівнянні $з$ відомим прототипом.
\end{abstract}

Ключові слова: ефективність, економія, паливо, дослідження, обробка, грунт, торсіонноударний ніж.

Постановка проблеми. Сучасні грунтообробні знаряддя, призначені для основного безвідвального обробітку грунту, належать до металоємких та енергонасичених машин. Ці знаряддя агрегатуються 3 більш енергонасиченими тракторами, що споживають значну кількість дизельного палива на гектар обробленої площі. Вартість палива порівняно висока (нині становить 9,90 грн/л), а якість обробітку грунту деякими агрегатами не завжди задовольняє вимоги, що відповідають найкращим умовам для вегетації рослин. Тому зменшення витрати палива на гектар обробленої площі, в поєднанні з удосконаленням конструкції грунтообробних агрегатів, спрямована на покращання показників якості обробітку грунту, $\epsilon$ комплексною науковотехнічною проблемою. Вирішення іiі повинно базуватися на пошуку нових конструктивних рішень, спрямованих на спрощення конструкції, що базується на теоретичному обгрунтуванні технологічних параметрів робочих елементів. Один із напрямів розвитку конструкцій робочих органів для основного безвідвального обробітку грунтується на використанні віброударної дії на грунт, що позитивно зарекомендувало себе 3 точки зору зниження енергозатрат й підвищило показники якості обробітку грунту.

Аналіз останніх досліджень та публікацій, у яких започатковано розв'язання проблеми. Останнім часом машини та їх робочі органи 3 вібраційним рухом набули широкого застосування у різних галузях виробництва $[1,2]$. Вібраційний рух надається робочим органам примусово від валу відбору потужності трактора або переважна їх більшість має в своїй конструкції пружні елементи - виті пружини або торсіон [3]. Існуючі нині технічні рішення реалізації вібраційної дії на грунт вирішують питання зменшення тягового опору та підвищують ефективність обробітку грунту. Проте єдиної методики 3 визначення техніко-економічної ефективності вищезгаданих активних грунтообробних знарядь допоки що немає.

У вирішенні поставленої задачі важливим $\epsilon$ реалізація питання визначення виробітку машинно-тракторного агрегату за годину основного часу роботи та витрата пального за зміну, а також розрахунок річного економічного ефекту використання торсіонно-ударного розпушувача грунту.

У літературі [4, 5] автори наводять рекомендації щодо визначення показників технікоекономічної ефективності, але загальної методики $з$ даного питання допоки не існує.

Мета та завдання досліджень. Встановити економічну доцільність запровадження нового технічного рішення глибокого обробітку грунту. Для вирішення мети необхідно експериментально встановити витрату палива при виконанні технологічного процесу безвідвального обробітку грунту машинно-тракторним агрегатом у складі МТ3-80 + торсіонно-ударний розпушувач грунту та порівняти отримані результати вико- 
нання аналогічної операції з прототипом. Провести техніко-економічні розрахунки.

Результати дослідження. Виробничі дослідження машинно-тракторного агрегату у складі МТ3-80 + торсіонно-ударний розпушувач грунту проводилися в період із 2010 року на полях ТОВ "Агрофірма ім. Довженка" Шишацького району Полтавської області при основному безвідвальному обробітку грунту на площі 198 гектарів. Агрофізичні властивості грунту знаходилися в межах, рекомендованих для проведення технологічного процесу. Агрофізичний фон - пар насичений бур'янами (див. рис.). У процесі виконання технологічної операції безвідвального основного обробітку грунту в першу зміну польова установка працювала за аналогом агрегату МТ3$80+$ ГРП 2,2 "Смугар" із жорстко закріпленими ножами, а в другу зміну різальні ножі мали можливість виконувати обмежені коливальні рухи (в крайніх положеннях з ударом) у вертикальній площині.

Наступного дня черговість встановлення жорстко закріплених та коливальних ножів змінювалася. У ході виробничих досліджень здійснювався хронометраж робочого часу та часу на технологічні зупинки машинно-тракторного агрегату, які передусім були пов'язані із забиванням ножів рослинними рештками та бур'янами (переважно за умови жорстко закріплених ножів). Окрім того вимірювали витрату палива імпульсним двопоршневим витратоміром палива ДРТ-ЛСХИ.
Виробіток за годину основного часу роботи торсіонно-ударного розпушувача грунту розраховували за формулою:

$$
W=0.1 \cdot B_{p} \cdot \mathrm{V}_{\mathrm{p}}
$$

де: $B_{p}$ - робоча ширина захвату агрегату, $B_{p}=2,2$ м; $\mathrm{V}_{\mathrm{p}}-$ робоча швидкість руху, $\mathrm{V}_{\mathrm{p}}=7,5$ км/год.

$$
W=0,1 \cdot 2,2 \cdot 7,5=1,65 \text { га/год. }
$$

Норму виробітку на механізовані польові роботи визначали за формулою:

$$
H_{b}=\frac{T_{3 M}-\left(T_{n .3}+T_{\text {вid }}+T_{o c . n}+T_{o б c}\right)}{60 \cdot\left(1+\mathrm{r}_{\text {noв }}+\mathrm{r}_{\text {nep }}+\mathrm{r}_{\text {доn. } p}\right)} \cdot \mathrm{W},
$$

де: $T_{\text {зм }}$ - тривалість зміни, $T_{3 .}=420 \mathrm{xв;} T_{n \cdot 3}-$ тривалість підготовчо-заключних робіт, $T_{n .3}=40$ хв; $T_{\text {sid }}$ - норматив на тривалість відпочинку впродовж зміни, $T_{\text {вid }}=25 \mathrm{xв} ; T_{o c . n}-$ час на особисті потреби, $T_{\text {oc.n }}=10$ хв; $T_{\text {обс }}-$ час обслуговування агрегату впродовж зміни, $T_{\text {обс }}=20 \mathrm{xв}$; $r_{\text {пов }}+r_{\text {пер }}+r_{\text {доп.р }}-$ коефіцієнт, відповідно поворотів, переїздів та інших допоміжних робіт $r_{\text {пов }}+\mathrm{r}_{\text {пер }}+\mathrm{r}_{\text {доп. }}=0,2$ год; $B_{p}=2,2$ м, (конструкційні параметри); $V_{p}=7,5$ км/год, (рекомендована за експлуатаційними показниками).

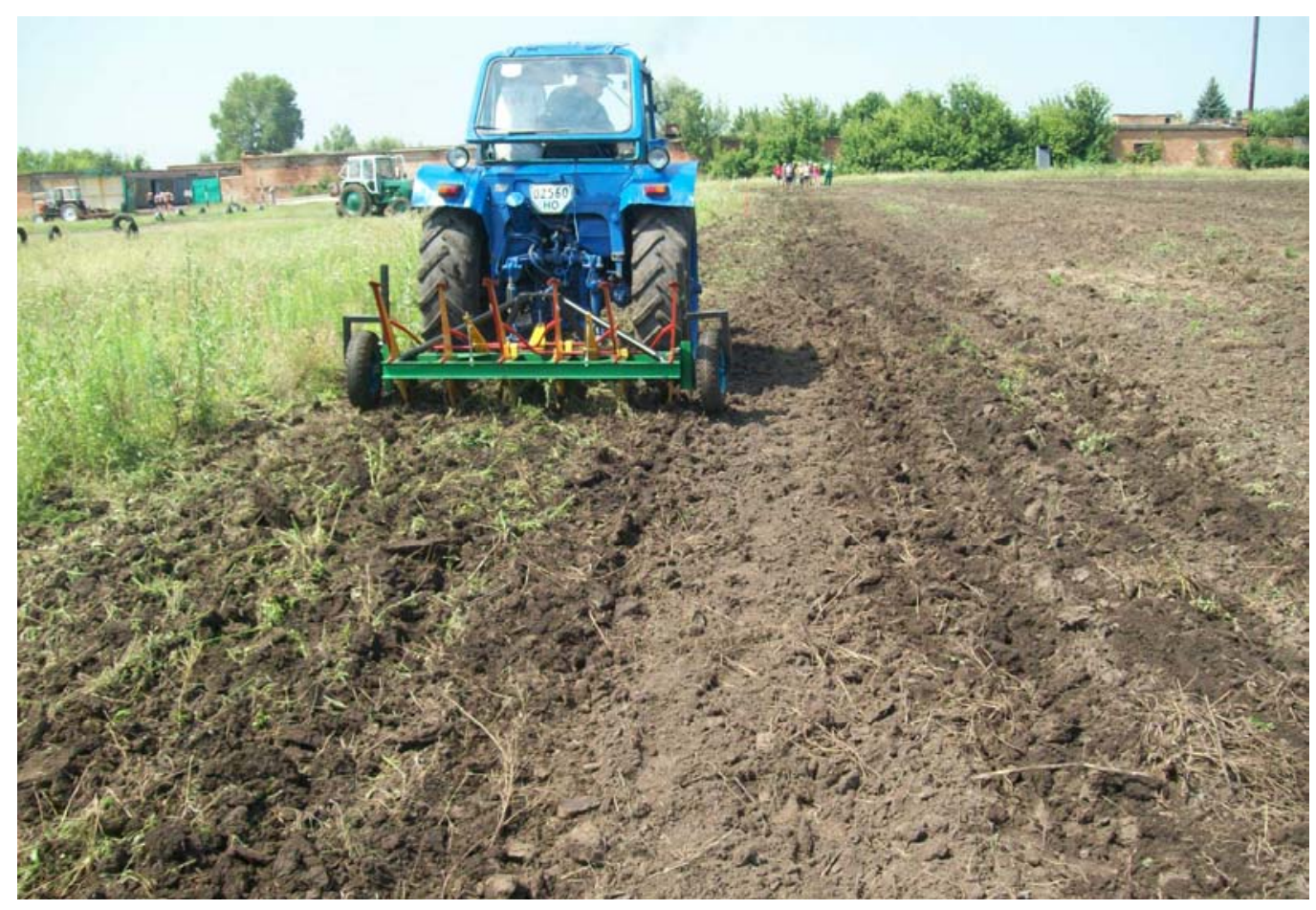

Рис. 1. Робота запропонованого трунтообробного агрегату по пару 
Техніко-економічні показники використання торсіонно-ударного розпушувача трунту

\begin{tabular}{|c|c|c|}
\hline Показник & $\begin{array}{c}\text { Базовий розпушувач } \\
\text { грунту з жорстко за- } \\
\text { кріпленими ножами }\end{array}$ & $\begin{array}{c}\text { Новий торсіонно- } \\
\text { ударний розпушувач } \\
\text { грунту з активними } \\
\text { ножами }\end{array}$ \\
\hline Вартість виготовлення, грн & 9846 & 12739 \\
\hline Ширина захвату, м & 2,2 & 2,2 \\
\hline Експлуатаційна продуктивність за зміну, га/зм. & 6,39 & 7,29 \\
\hline Експлуатаційна витрата палива, кг/га & 14,0 & 11,60 \\
\hline Вартість 1 га основного обробітку, грн & 145,74 & 121,70 \\
\hline $\begin{array}{c}\text { Термін окупності запропонованого нового } \\
\text { грунтообробного знаряддя, років }\end{array}$ & - & 0,71 \\
\hline Продуктивність нормативна, га/год & 0,91 & 1,04 \\
\hline $\begin{array}{c}\text { Економічна ефективність, використання одного } \\
\text { агрегату, грн }\end{array}$ & - & 5641,71 \\
\hline
\end{tabular}

Норма виробітку на основний безвідвальний обробіток грунту торсіонно-ударним розпушувачем становитиме:

$$
\mathrm{H}_{\mathrm{b}}=\frac{420-(40+25+10+27)}{60 \cdot(1+0,2)} \cdot 1,65=7,29 \text { га. }
$$

Витрату пального за зміну розраховуємо за формулою:

$$
Q=\frac{q_{x} \cdot T_{x}+q_{p} \cdot T}{60}
$$

де: $q_{x}-$ витрата пального при роботі двигуна в режимі холостого ходу, $q_{x}=3,61$ кг/год, (паспортні дані двигуна); $q_{p}$ - витрата пального при роботі двигуна в режимі навантаження, $q_{p}=14,80$ кг/год (за даними вимірювань імпульсного поршневого витратоміра палива ДРТЛСХИ); $T_{x}-$ тривалість часу зупинок, $T_{x}=40+25+10+27=102$ хв; $T-$ тривалість робочого часу, $T=T_{p}-T_{x}=420-102=318$ хв.

$$
Q=\frac{3,61 \cdot 102+14,8 \cdot 318}{60}=84,58 \text { кг. }
$$

Як видно з розрахунків, що за зміну машиннотракторний агрегат у складі МТЗ-80 + ТУР-2,2 виконає основний безвідвальний обробіток грунту в обсязі 7,29 гектарів. При цьому витрата палива становила 84,58 кілограм. На обробіток 198 га машинно-тракторному агрегату у складі МТ3-80 + ТУР-2,2 знадобилося 190,12 годин, при цьому витрата пального склала 2297,23 кг, що в грошовому перерахунку (при вартості дизельного палива 9,90 грн) становить 22742,58 гривні. Порівняльні дані розрахунків зводимо в таблиці 1.
Оскільки результати експериментальних досліджень підтвердили, що основною перевагою запропонованого торсіонно-ударного розпушувача грунту $є$ можливість зменшення тягового опору за рахунок використання активних ножів, що, в свою чергу, безпосередньо пов'язано 3 економією палива, то річна економічна ефективність від впровадження й використання нових засобів праці довгострокового використання 3 поліпшеними характеристиками становитиме 5641,71 гривні.

\section{Висновки:}

1. Отримані дані в ході проведених виробничих досліджень підтвердили високу експлуатаційну ефективність роботи торсіонно-ударного розпушувача грунту. Економічна ефективність від використання нового грунтообробного агрегату в складі трактора МТ3-80 на площі 198 га склала 5641,71 грн, що становить у середньому 28,49 грн/га обробленого поля за рахунок зменшення: тягового опору (внаслідок використання віброударної дії на грунт); технологічних простоїв на очищення робочих органів від грунту та рослин (використання коливальних робочих органів створює ефект самоочищення); збільшення продуктивності праці та економії пального.

2. Економія витрати палива в ході виробничих досліджень у середньому 2,4 кг/га, що в перерахунку на оброблену ділянку 198 га становить 475 кілограмів. При вартості дизельного палива 9,90 грн сумарна економія коштів на паливі склала 4705 гривні.

3. Термін окупності додаткових витрат на запропоновану конструкцію торсіонно-ударного розпушувача грунту становитиме 0,71 року. 


\section{БІБЛІОГРАФІЯ}

1. Бабицкий Л. Ф. Состояние и направление разработки чизельных вибрационных рыхлителей почвы. / Бабицкий Л. Ф., Москалевич В. Ю. // Механизация сельськохозяйственного производства: (Сб. науч. тр.) - Симферополь: Крымский ГАУ. - 2002. - С. 10-14.

2. Дубровський A. А. Вибрационная техника в сельском хозяйстве / А. А. Дубровский. - М.: Машиностроение, 1968. - 204 с.

3. Пат. Україна, А01В 39/00. Торсіонно-ударний розпушувач грунту / С.В. Ляшенко (Україна). -
№ 61579; заявл. 12.12.10; опубл. 25.07.11, Бюл. № 14. - C. 31 .

4. Мазнєв Г. Е. Економічне обгрунтування інженерних рішень у сфері АПК. / Навч. посібник / Мазнєв Г. Е., Турченко М. М., Щетиніна М. Д. Х.: ХДТУСГ, 2001. $-401 \mathrm{c}$.

5. Механізовані польові роботи. Методика розрахунку, норми виробітку та витрат палива на основний обробіток грунту. Кн. 2 / За ред. В. В. Вітвіцького. - К.: ТОВ Комплекс Віта. 1997. $-274 \mathrm{c}$. 